E-Journal of Tourism Vol.8. No.1. (2021): 23-33

\title{
Stakeholder's Perceptions about Sustainable Tourism in The Main Attraction of Banda Aceh Halal Tourism (Baiturrahman Great Mosque)
}

\author{
Muhammad Baiquni ${ }^{1}$, Heriani $^{2 *}$ \\ ${ }^{1}$ Tourism Studies, Gadjah Mada University, Indonesia \\ ${ }^{2}$ Universitas Terbuka, Indonesia \\ *Corresponding Author: heriani@ecampus.ut.ac.id \\ DOI: https://doi.org/10.24922/eot.v8i1.68442
}

Article Info
Submitted
December $30^{\text {th }} 2020$
Accepted
March $18^{\text {th }} 2021$
Published
March $31^{\text {th }} 2021$

\section{Article Info}

Submitted

December $30^{\text {th }} 2020$

Accepted

Published

March $31^{\text {th }} 2021$

\begin{abstract}
Mosque is place of worship as well as religious symbols that have religious and social aspects. The aspects can be used as places of worship, while social aspects are referred to as places of community activity, places of learning, cultural development, art of building, even in times of war for Acehnese fighters. But in the current era of globalization, mosques are no longer a place of worship, but also a tourist destination for both Muslims and non-Muslims. There are three the main halal tourism destinations Indonesia, they are West Sumatra, West Nusa Tenggara and Aceh Province. The addition of material directly is very important, especially in terms of control and physical appearance of the mosque. The Baiturrahman Mosque in Banda Aceh is one of them, since 2015 major improvements have been made enough to restore the face of the historic mosque. This study is a case study that tries to explore the in-depth perspective of several informants regarding sustainable tourism, focusing on mosques as halal tourism attractions. Data collection techniques used are observation, in-depth interviews, and documentation. This research is expected to be able to find out (a) the attraction of Baiturrahman Great Mosque (b) to explore the deep perspectives of stakeholders regarding sustainable tourism, in this case concerning the Baiturrahman Mosque as the main attraction of Halal tourism in Banda Aceh. The results of this could be as input and consideration for the development of halal tourism, especially the development of tourism in other mosques in Aceh Province and Indonesia.
\end{abstract}

Keywords: stakeholders, attraction, halal tourism, sustainable tourism

\section{INTRODUCTION}

The development of information technology at this time raises the post-truth era in which various kinds of change are found, especially social change. Community access to information has been very easy, on the one hand is a positive thing for the development of society, but on the other hand the negative impact is also very large. A lot of information and scattered are sometimes difficult to distinguish which are really facts and which are fictitious (lies) or the trend is called a hoax. Communities 
easily access and generally disseminate it without ensuring that the information is true. The most sensitive and viral issues in the mass media that are usually directly divided are usually religious or political issues. Conflict and various conflicts can eventually arise in the community from small to large scale. Facilities of worship such as mosques with their social function can be a hope to help inform and provide knowledge about the facts that are true, so that people are not easily carried away by emotions only in responding to various information available.

The mosque is generally known as a building where muslims worship. The word "mosque" comes from Arabic, namely "sajada, yasjudu, sajdan". "Sajada" means "bowing with solemnity, prostration, and kneeling". To show a place, the word "saja$d a$ " was changed into "masjidan" meaning "place to worship Allah ". The word mosque is referred to in the Al-Qur'an 28 times, this indicates the importance of the mosque's position for Muslims. Mosques are religious symbols that have religious and social aspects. According to Jalil (2012), the religious aspect is seen from its function as a place of worship, while the social aspect is based on its function as a place of learning, cultural development, building art, a place of community activities such as a place of community learning in addressing social media information, even in times of the war of independence of the Acehnese fighters sometimes made the mosque a stronghold.

One of the mosques of the pride of the people of Aceh is the Baiturrahman Grand Mosque. This mosque is not only an icon of the city and tourism in Banda Aceh, but is a witness to the history of Aceh's civilization from the era of the glory of Iskandar Muda (1614), the era of Dutch colonialism, until the devastating tsunami waves swept through the city of Banda Aceh. After experiencing a number of extensions, the area of Baiturrahman Grand Mosque is currently around 4 hectares in which there is a pond, a main tower, 7 domes, 4 towers, and 1 main tower.

Baiturrahman Grand Mosque currently has a new face, a major renovation which is a mega project that began in 2015 . The renovation was centered on the courtyard of the mosque which was done hardening, the yard that was once overgrown with green grass was replaced with imported marble floors. Then various kinds of palm trees and geulumpang (Aceh's language) trees which are historic trees have also been replaced with electric umbrellas such as the Nabawi Mosque in Medina. Toilet facilities, ablution places, and parking in the basement are made in a class of star hotels. Some parties and various media outlets discussed and praised the beauty and splendor of the new face of the Baiturrahman mosque and some also saw that it was an urgent need of the people and supported tourism in the Baiturrahman Grand Mosque.

Reparation, renovation and addition of aesthetics and facilities of the mosque which is a tourist destination ideally can provide comfort for the people in worship and make a positive contribution to increasing tourism. The big question is whether the stakeholders of Baiturrahman Grand Mosque have been paying attention to the principles of sustainable tourism in the renovation, which will be explored through the following research questions: What are the potential and attractions of tourism Baiturrahman Grand Mosque?; What are the stakeholders' perceptions about Sustainable Tourism, related the project of renovating Baiturrahman Grand Mosque Banda Aceh?

\section{LITERATURE REVIEW}

\section{Halal Tourism}

Halal Tourism is one of the new concepts that are developing in the world to- 
day, which continues to grow by the world. In 2010 the population reached 1.6 billion people from 5.3 billion inhabitants of the world population $(23.4 \%$ of the total soul population in the world) and is expected in 2020 to be 1.9 billion people from 5.8 billion people of the world or around $24.9 \%$ of the total soul in the world (Pew Research Center forum on religion \& Public Life, 2011). The large population of the Muslim world directly encourages the world of tourism.

According to Shakiry (2006), the concept of Islamic Tourism (Islamic Tourism) or halal sports is not only limited to religious tourism, but extends to various forms of tourism, because it does not conflict with Islamic values. This activity includes principles to respect local customs and customs, and care for the environment, bring back values, ethics and morality in the midst of a culture of consumerism that is rampant and encourages understanding and dialogue between countries, cultures and different civilizations to find out about the background of the community and different relics.

\section{Religious Tourism and Mosque Tour- ism; Main Supporters of Halal Tourism}

Religious Tourism is one of the various other tours in the concept of Halal Tourism. Although Halal tourism does not have to be in the form of religious tourism, it is undeniable that Halal tourism relies heavily on destinations and religious attractions. Religious Tourism is a tourism based on belief in a religion, with the aim of increasing faith and belief in the religion. FICCI report and YES BANK Ltd. (2012) entitled "Diverse Beliefs: Tourism of Faith Religious tourism gains ground" defines religious tourism as "a journey with the main motives of gaining experience from various religious forms, or products they produce, such as art, culture, tradition and architecture (Sharma, 2016)
Mosque tourism is a form of religious tourism. The development and growth of tourism in Islamic countries has given birth to new innovations in promoting mosques as tourism centers. According to Shafaei and Mohamed (2017), the mosque has become one of the popular destinations among local and international tourists as part of an attractive tour package. The attractiveness of each mosque is different, some have the attraction of the beauty of the architecture of the building, interesting religious activities / events, the atmosphere of the mosque, mosque management, as well as the history and events that have occurred in the mosque. Besides that, comfort and service are the main support for mosque tourism. Mansor's research (2015) describes the importance of providing and certifying mosque tour guides to support services and comfort for both pilgrims and tourists.

\section{Tourist attraction}

Each region tries to develop its potential as a tourist attraction for tourists. Damanik and Weber (2006) state that tourist attraction is an object that has uniqueness, originality, authenticity, and diversity. Now, the object of tourist attraction is becoming increasingly diverse, one of which is the tourist attraction that is owned by places of worship, such as mosques. Sofyan (in Republika 2018) stated that there are 3 important aspects that must be owned by mosque-based tourist destinations, namely comfort, service and attractiveness. The tourist attraction of the mosque which is intended to open only relies on the beauty and architecture of the mosque, but can be in the form of creative activities initiated by mosque managers. The historical and philosophical value of the mosque must also be maintained as a characteristic and attraction for tourists. 


\section{Sustainable Tourism}

Tourism is like two sides of a coin, can bring profit or loss. The advantage of the tourism sector is undoubtedly, because in addition to increasing the income of a country or region, it also directly revives the economy of the community, although sometimes it is not as lucky as the investors of big tourism and of course open wider employment opportunities. Behind the benefits, tourism can also bring negative things, such as pollution and environmental damage, cultural shifts and others. Jenkins (2013) describe that:

"Sustainable tourism is closely linked to the natural environment, is socially acceptable and is empathetic to the culture and the environment of a destination. Environmental protection, current social structures and culture can all be seen as providing an economic boom for a region. But the emphasis should be on advocating new developments that secure the needs of future generations as well as providing for the needs of the present."

From the statements, it is understood that Sustainable tourism is part of sustainable development by considering the needs at this time by not ignoring the ability of future generations to meet their needs. Over time, the concept of sustainable development was adopted into the concept of Sustainable Tourism Development. Sustainable tourism development is interpreted as a tourism development process that is oriented towards the sustainability of the resources needed for future development. Sustainable tourism can simply be defined as tourism that takes full account of current and future economic, social and environmental impacts, meeting the needs of visitors, industry, the environment and local communities.

There are 7 guiding principles for achieving sustainable tourism develophttp://ojs.unud.ac.id/index.php/eot ment, according to Burns and Holder (1997) in Suwena (2010), namely: "First, the environment has intrinsic value that can also function as a tourism asset. Its utilization is not only for short-term interests but also for the benefit of future generations. Second, tourism must be introduced as a positive activity that provides mutual benefits to the community, the environment and the tourists themselves. Third, the relationship between tourism and the environment must be made in such a way that the environment is sustainable for the long term. Fourth, tourism and development activities must be concerned about the natural scale / size and the character of the places where these activities are carried out; Fifth, in other locations, harmony must be built between the needs of tourists, place / environment, and the community; Sixth, a world that tends to be dynamic and full of change can always provide benefits. Adaptation to change, however, don't get out of these principles. Seventh, the tourism industry, local government, and environmental watchdog organizations (NGOs), all have the duty to care about the principles above and work together to make it happen. Damanik and Weber (2006) then conclude that there are 3 dimensions of sustainable tourism that must be the concern of all parties, namely the environmental, social and cultural, and economic dimensions.

\section{Sustainable Mosque}

The term sustainable mosque is classified as still very rarely heard, but the concept is actually not new in the teachings of Islam. Continuous mosque is a mosque that can be a bridge between the human relationship with the Creator (habluminallah), the relationship between humans and humans (habluminannas) and the relationship between humans and the environment (habluminal'alam). These three things are the main aspects of a sustainable mosque concept that should be considered in pros-

e-ISSN 2407-392X. p-ISSN 2541-0857 
pering each mosque (Sapri et al., 2014).

Most people have been aware that the mosque is only for the afterlife, that is our relationship with God. In addition, the construction of the mosque is also identified with physical development that can be said to be endless and satisfied. construction of facilities or renovating parts of the mosque that are not needed are facts that are common in the field. Some people also have the view that a good mosque is a mosque with a magnificent building, some mosque managers and worshipers also compete to show that the mosque is the most magnificent. Mosques that are also tourist destinations began to slowly turn their faces into majestic. The renovation, expansion to increase grandeur was carried out with the main reason that development was the capacity of pilgrims. Baiquni and Susilawardani (2002) suggest that sometimes various phenomena around us are seen and claimed as a development, but in fact it actually does damage, as is the case with various renovation activities of the mosque. Looks for the good of the mosque, but it turns out that the action actually damages the mosque. Therefore, the concept of sustainable mosque is an urgent matter to be socialized, so that managers, worshipers and Muslims know and implement sustainable mosque management.

\section{METHOD}

This research was carried out in the city of Banda Aceh, precisely in Baiturrahman Grand Mosque located in Gampong Baru, Baiturrahman which is a landmark of the city of Banda Aceh, as well as the main tourism icon of the city dubbed the foyer of Mecca (Serambi Mekkah). This research is a qualitative research with a case study approach. Baiturrahman Great Mosque, one of the largest and historic mosques is also known as a religious tourism destination in the city of Banda Aceh, chosen as the ob- ject of research. The method used in data collection includes literature review, open interview, observation, electronic data search and document review from various sources related to the object of research.

Data analysis is an activity that is essentially to give meaning or interpret data by organizing, sorting, grouping, giving codes or signs, and categorizing them into sections based on certain groupings so that a finding is found on the proposed problem formulation. Through a series of activities, qualitative data that is usually scattered and stacked can be simplified so that it can be understood more easily.

\section{RESULT AND DISCUSSION}

\section{The Main Tourist Attraction of Baitur- rahman Grand Mosque}

Tourist attractions according to Damanik and Weber (2006) are objects that have uniqueness, originality, authenticity, and diversity. Mosque tourist attraction which is intended not only rests on the beauty and architecture of the mosque, but can be in the form of creative activities initiated by mosque managers. The historical and philosophical value of the mosque must also be maintained as a characteristic and attraction for tourists. Based on observation activities, in-depth interviews supported by literature and document search, Baiturrahman Great Mosque has several tourist attractions, namely:

\section{The Mosque's Architecture as Attrac- tion}

Baiturrahman Grand Mosque which is the pride of the people of Aceh was built during the reign of Sultan Iskandar Muda (1607-1636 AD), but had experienced a great fire during the Dutch military aggression in 1873, when the roof of the mosque was still rumbia. This mosque has been renovated several times by both the Dutch East Indies government and the last 
regional government of the Baiturrahman Grand Mosque renovated since 2015 and was inaugurated in early 2017 . This mosque is located in downtown Banda Aceh with a building area of $3,500 \mathrm{~m} 2$, which is equipped with seven domes, five towers with seven entrances. One of America's largest online media, the Huftington Post confirms this mosque in the 100 most beautiful mosques in the world. While Yahoo enters the Baiturrahman Mosque into the 10 most amazing mosques in the world (Sungkar, 2015).

\section{Religious Atmosphere of The Mosque as Attraction}

Baiturrahman Mosque as a sacred place and worship for Muslims has a variety of religious activities which usually become its own attraction for tourists to come to attend, such as the grand tabligh, activities of Ramadan, maulid and other religious activities.

\section{Historical Attraction of the Mosque}

Baiturrahman Mosque is not only a tourism icon of the city of Banda Aceh, but is the main icon of the city of Banda Aceh, even a symbol of Aceh's pride. Anyone visiting Aceh will feel incomplete if you don't visit a historic mosque which is a witness to the glory of Iskandar Muda, the era of Dutch occupation and the enormity of the tsunami of December 26, 2004. When people, buildings, trees fell and were destroyed, thousands of bodies were scattered -Where, this mosque remained solid and was a refuge for thousands of Acehnese people at that time. A tourist from Malaysia told me:

"This mosque is certainly a beauty, of course. After all, the history of our tsunami is understandable if the mosque is in effect, this mosque is a mosque where the place is safe. Right " $(R S M)^{l}$

${ }^{1} \mathrm{RSM}$ : Initial name of informant to save her/his http://ojs.unud.ac.id/index.php/eot
"Yes, beautiful, this one is beautiful and the history also exists, so he is like combined one of the big ones that is not neglected according to it, in Malaysia there are many beautiful mosques, but we go where people first, yes it is indeed an unspoken history ok ok lah.so far ok. "(RSM)

RSM expressed its main interest in visiting Baiturrahman Grand Mosque as the historical value of the mosque, especially because of the history of the mosque as one of the mosques that survived the tsunami. According to RSM in his country there are indeed many magnificent and beautiful mosques, but the history and story of a mosque can defeat it all.

The historical attraction of the Baiturrahman Grand Mosque is a great potential that must be developed and managed properly as stated by Sofyan (2018) that if you want to highlight the history of the mosque as an attraction, the most important thing to do is display historical evidence in the form of relics. relics and historical explanation. Therefore, Baiturrahman Mosque needs to be equipped with a historical gallery or museum that displays various historical collections and stories about the mosque, so that tourists or local people can easily find out more about the history of the mosque.

\section{Spiritual Attraction of the Mosque}

Norman (2014) suggests that spiritual tourism is a type of tourism whose motives are to admire, explore and learn and take lessons from all of God's creations and events that occur in the world, whether buildings, historical heritage, nature, or the graves of religious people, heroes and religious leaders. By looking at the evidences of the greatness of God, humans can become individuals who are good at giving thanks for the gifts they have given and can learn valuable lessons for their lives, whether religious or not. The experiences of spi-

privacy. e-ISSN 2407-392X. p-ISSN 2541-0857 
ritual tourism will usually create peace of mind and inner satisfaction. According to Norman (2014), the main point of spiritual tourism is the motivation or intention of tourists.

Some tourists who visit the Baiturrahman Great Mosque in Banda Aceh are not only Muslim tourists, but many nonMuslim tourists visit the mosque with different motivations, as some international tourists have talked to and chat with them. The main motive for their visit to the Baiturrahman mosque is that they want to see the mosque directly which is the pride of the people of Aceh and is one of the places of worship that survived and survived the 2004 tsunami and the people who took refuge there survived. They want to get the spiritual atmosphere at the Baiturrahman mosque.

\section{Baiturrahman Great Mosque Stake- holder Perceptions about Sustainable Tourism, related to the $2015-2017$ reno- vation}

Environment is one of the important factors that must be considered in any tourism development. Environment is the main resource of tourism that must be ensured its sustainability and sustainability. The environmental aspect of the Baiturrahman Grand Mosque is very important to be studied, moreover it has just been renovated since 2015-2016.

Various views emerged from several stakeholders regarding the environmental conditions of the Baiturrahman mosque during the renovation and completion of the mosque. One of them was disclosed by MI informants:

"Why is there a megaproject... because tourist arrivals continue to increase while the capacity of the supporting facilities starts parking is narrow, so now it has been built to win the customary style of the city. and also supporting facilities for congregants with disabilities, disabled people”.

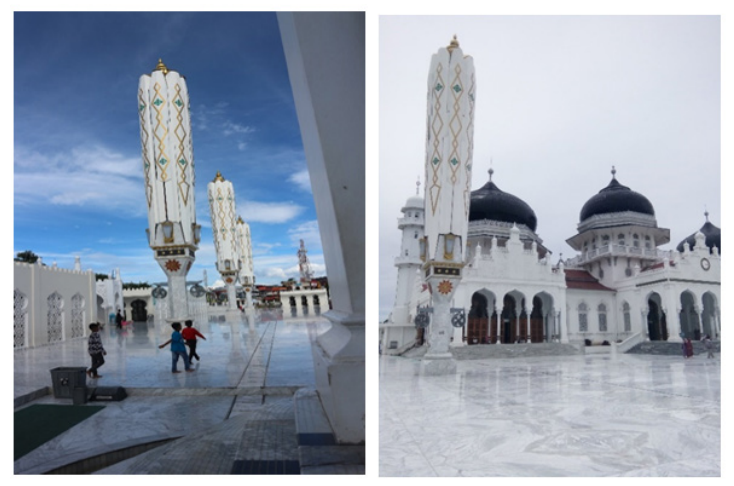

Figure 1. Electric Umbrellas that are not open. Source: Researcher Documentation (2018)

The next informant is JM who has almost the same perception as MI, he said:

"First, people worship easily ... then the second is something new, well ... something is different from other places, so that is why the Aceh government is working on this, although there are pros and cons, there is no harm."

JM stated that the renovation of the grand mosque was mainly intended for ease of worship and the second important thing according to him was by giving these electric umbrellas a unique and unique way that hopes to attract more worshipers and tourists, both domestic and foreign tourists to visit Baiturrahman Grand Mosque, Banda Aceh. JM also explained that the renovation was indeed colored by the pros and cons of its implementation. The following informant is one of the different voices from previous informants regarding the renovation. As stated by WA informants:

"This banda aceh grand mosque is actually criticizing us like this, please build it, but the green open space should not be damaged, which is one of the trees that has a long historical value, whether it is an acid tree or all kinds"

e-ISSN 2407-392X. p-ISSN 2541-0857 
WA added that:

"So.. there is indeed a type of tree plant which in our opinion has been a solution to overcome the green open space, because it is getting narrower"

WA did not refuse to develop and renovate it, but the important point from the environmental aspect highlighted by the renovation by WA is the green open space of Baiturrahman Mosque which consists of grasses and various trees, including trees that have a long historical value in Aceh history to remain maintained and preserved. The following is a picture of the condition of Baiturrahman Grand Mosque before renovation.

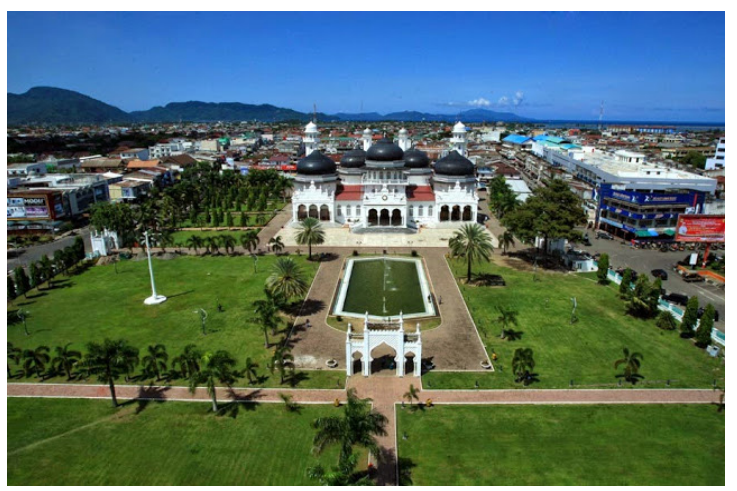

Figure 2. Baiturrahman Great Mosque Before Renovation with Green Open Space. Source: YR's Photo, Informant Collection (2015)

The Figure 2 is the condition of Baiturrahman Grand Mosque with a stretch of green grass and shady trees before renovation. When the renovation megaproject will begin, one by one the trees begin to be cut down, including large trees which are replanted to mark and remember the history of the Acehnese struggle that took place in the mosque. Tree logging continues and the mosque's yard is possible and replaced with marble floors. Furthermore, the felled trees were replaced by installing electric umbrellas on several sides of the mosque. Then some facilities are built such as par- king, toilet where ablution, stairs lift to the basement then there are two pathways for disability. The following picture is the condition of the mosque after renovation.

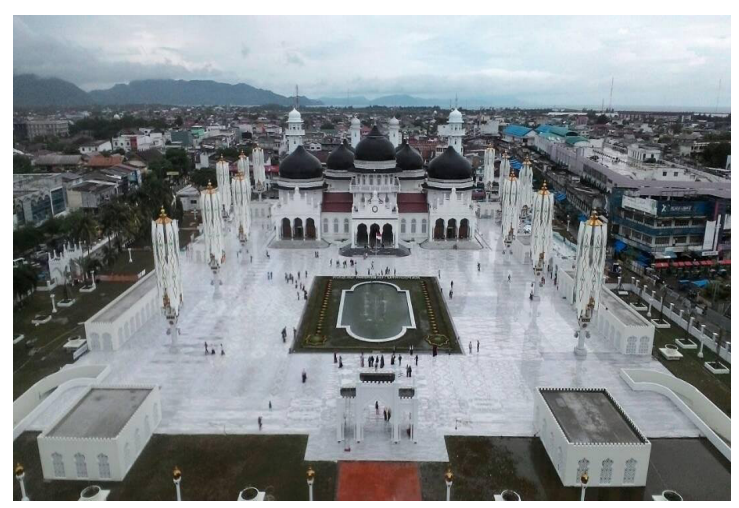

Figure 3. Masjid Raya Baiturrahman After Renovation. Source: Photo Collection of Habib Razali (2017)

An informant expressed his opinion about Baiturrahman Great Mosque. $\mathrm{YI}^{2}$ said:

"If I think personally, the umbrellas of the grand mosque reduce the beauty of the Masjid Raya Baiturrahman, used to be more beautiful with trees, now arid and hot"

YI believes that the current condition of the Grand Mosque is not as beautiful and comfortable as before, although various additional facilities exist. But the cool atmosphere in the courtyard of the Great Baiturrahman Mosque used to make anyone feel at home sitting while doing various activities on the grass and under shady trees, even in the sunny day there was no more. Based on the observations of the author, during the day it will feel so hot and the soles of the feet feel very sore walking on the hot floor, moreover there are none of the umbrellas that are open and functioned as heat protectors.

\section{Social and Culture}

An important aspect of further deve-

${ }^{2} \mathrm{YI}$ : Initial name of informant to save her/his privacy.

e-ISSN 2407-392X. p-ISSN 2541-0857 
lopment is Social and Culture. One important social dimension according to Daman$\mathrm{ik}$ and Weber (2006) is to involve as much as possible in planning, implementation and monitoring. One of the WI Informants revealed:

"Our voices are lacking or more are not heard by those who have higher authority in managing the Grand Mosque compared to us, we often announce various things related to mosque service or management, but it is easier to respond".

\section{$\mathrm{WI}^{3}$ added:}

"We have never been invited to sit together talking to the renovation plan, suddenly it starts suddenly"

Stories and opinions of Informants There is a vision of a communication channel between the stakeholders of the Baiturrahman Great Mosque that has not been well established. There is still dominance of one of the stakeholders in the decision making and storage of the mosque.

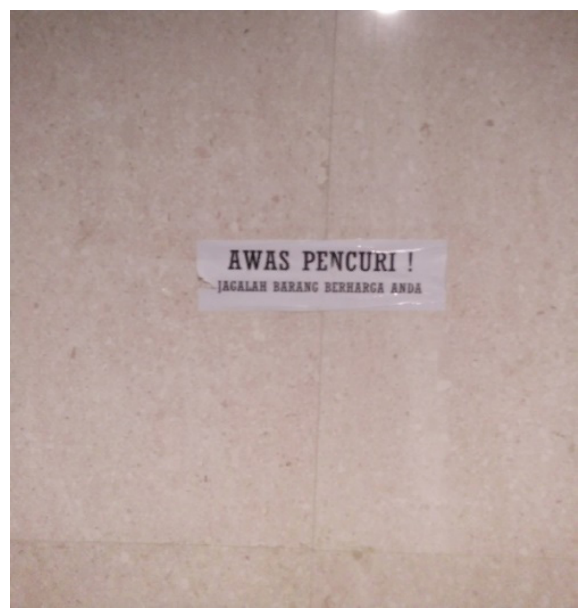

Figure 4. Warning sticker in the mosque. Source: Researcher Documentation (2018)

The Figure 4 of an announcement containing warnings to alert thieves because there have been many cases of theft of goods, especially tourists who are on the ${ }^{3} \mathrm{WI}$ : Initial name of informant to save her/his privacy.

http://ojs.unud.ac.id/index.php/eot toilet and ablution place, even information from one of the mosque managers that the motorbike of the Baiturrahman Grand Mosque mosque was parked too missing a few months ago. Announcement board is not only one, but is in several angles. It is also a very serious social problem, which shows the security system of Baiturrahman Grand Mosque which is still weak. A mosque is a place of worship, a sacred place, a house of God that should be the safest place and no crime, but it is now increasingly common in Baiturrahman Mosque .

The next important dimension where development must protect and maintain cultural heritage, historical heritage, and local wisdom is Culture, Some informants expressed a lot about the cultural dimension related to the renovation of the Baiturrahman Grand Mosque. One of them is about historical relics in the form of trees that have long been replanted replacing the original trees that function like monuments or monuments commemorating the history of the struggle of the Acehnese people in the mosque. WA informant said:

"The issue that we are developing is saving some trees that have histories that are sites in our opinion, the site of why the trees planted by the first people that are a sign that the entrance of the main mosque but ended also was cut down".

The tree that functions like a historical monument is the Geulumpang Tree (Aceh language), but it is more familiarly called the Kohler tree because under the tree a Dutch general named Kohler who wanted to burn and destroy the grand mosque which also functioned as a fortress was shot dead by the Acehnese from the mosque's main terrace. The original tree has long been developed and the wood is deviated in the Aceh museum, and then replanted similar trees and in the same place until they grow again into old trees until finally felled again before the renovation of

e-ISSN 2407-392X. p-ISSN 2541-0857 
the mosque.

Cultural wisdom and local beliefs related to the Baiturrahman mosque are also found in the people of Banda Aceh, as stated by $\mathrm{YR}^{4}$ :

"Take him to the courtyard of the mosque, open his footwear, set him up on the grass, then wipe both of his thighs and calves with moisture from the grass in the courtyard of the mosque"

YR told about the local belief of the local community that if there were toodler who could not walk, it was suggested to be taken to the mosque yard in the morning and touched his feet to the grass which was still wet with moisture, with Allah's permission the child could walk immediately. However, after the renovation of the mosque and the hardening of the mosque's yard, the local wisdom was difficult to find because there was no more grass in the courtyard of the mosque.

\section{Economy}

The third dimension of sustainable tourism is Economics. One aspect of the economy is about increasing and equalizing income and business opportunities for local communities (Damanik and Weber, 2006). This economic dimension is the only one of the three dimensions that still persists and there is no change very far from time to time. Since the time of the kingdom, the Baiturrahman mosque was always side by side with the market, the economy of the community around the mosque was so vibrant. Currently, there are also many souvenir shops around the main mosque, traditional coffee shops and food stalls. Even motorbike rickshaws which are local transportation are still many and faithfully waiting for the public and tourists to use their services, even though online transportation already exists in Banda Aceh.

\footnotetext{
${ }^{4}$ YR: Initial name of informant to save her/his privacy.
}

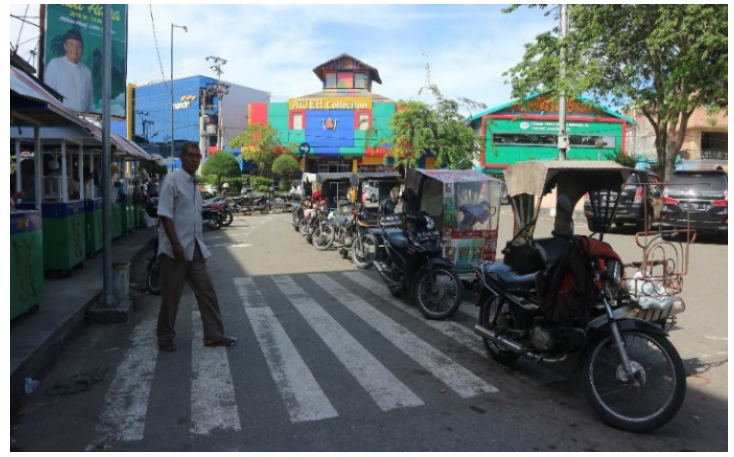

Figure 5. Motorized Becak parked in front of Baiturrahman Grand Mosque. Source: Researcher Documentation, 2018

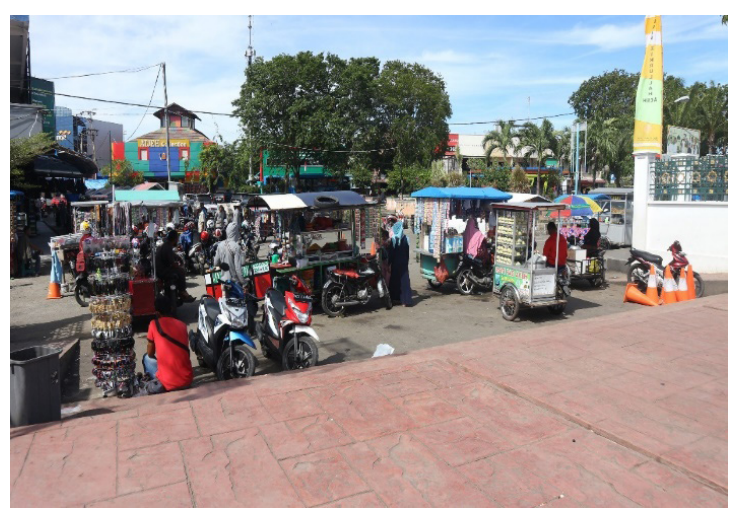

Figure 6. Street vendors at Baiturrahman Grand Mosque. Photo Source: Researcher Documentation (2018)

Some street vendors also feel the economic impact of the visits of various guests at the Grand Mosque, especially local tourists and bring families, especially children. But unfortunately the arrangement of the street vendors has not been done and arranged properly so as not to leave the impression of slums at the entrance of the mosque.

\section{CONCLUSION}

Baiturrahman Grand Mosque Banda Aceh has a variety of tourist attractions that must be maintained and managed well . Sustainable tourism is an important concept to be a guide in every development and management of each of these tourist attractions. Based on extracting informati- 
on about the perspectives of stakeholders the Baiturrahman Grand Mosque regarding sustainable tourism concluded that not all stakeholders have an understanding of important aspects of sustainable tourism. The main man ement authority of the Masjid Raya Baiturrahman has not applied all the principles of sustainable tourism, especially after the renovation of the mosque. Some environmental, social and cultural issues arise after the renovation, and now is the time to fix one by one with management based on the principles of sustainable tourism and the principle of openness to receive input and criticism from anyone.

\section{REFERENCES}

Baiquni, M. and Susilawardani (2002) Pembangunan yang tidak berkelanjutan: refleksi kritis pembangunan Indonesia. Transmedia Global Wacana.

Damanik, J. and Weber, H. F. (2006) 'Perencanaan ekowisata', Yogyakarta: Penerbit Andi.

Jalil, L. A. (2012) Arsitektur Masjid Kuno di Aceh; Kajian terhadap MasjidMasjid Kuno di Pesisir Aceh. Banda Aceh: Bandar Publishing.

Jenkins, I. (2013) Sustainability in Tourism A Multidisciplinary Approach. Swit- zerland: Springer Gabler.

Norman, A. (2014) 'The varieties of the spiritual tourist experience', Literature \& Aesthetics, 22(1).

Sapri, M. et al. (2014) 'Potential of facilities management in uplifting mosque management functions', in International Conference on Masjid, Zakat and Waqaf (i-MAF), pp. 1-13.

Shafaei, F. and Mohamed, B. (2017) 'Malaysia's branding as an Islamic tourism hub: An assessment', Geografia-Malaysian Journal of Society and Space, 11(1).

Shakiry, A. S. (2006) 'Islamic Tourism, for whom?', Islamic Tourism Magazine. Available at: www.IslamicTourism. com.

Sharma, R. (2016) 'Evaluating total carrying capacity of tourism using impact indicators', Global Journal of Environmental Science and Management, 2(2), pp. 187-196.

Suwena, I. K. (2010) 'Format Pariwisata Masa Depan" dalam Pariwisata Berkelanjutan dalam Pusaran Krisis Global', Denpasar: Penerbit Udayana University Press. 